Metallophysics and Advanced Technologies Металофіз. новітні технол. Metallofiz. Noveishie Tekhnol. 2019, vol. 41, No. 2, pp. 203-211

https://doi.org/10.15407/mfint.41.02.0203 Reprints available directly from the publisher
2019 G. V. Kurdyumov Institute for Metal Physics, National Academy of Sciences of Ukraine Published by license under the G. V. Kurdyumov Institute for Metal PhysicsN.A.S. of Ukraine Publishers imprint. Printed in Ukraine.

PACS numbers: 06.60.Vz, 62.20.Qp, 81.05.Bx, 81.20.Vj, 81.40.Cd, 81.40.Pq, 81.70.Bt

\title{
Wear Behaviour of Friction Stir Welded Dissimilar Aluminium Alloys
}

\author{
R. Ashok Kumar and M. R. Thansekhar
}

\author{
K.L.N. College of Engineering, \\ 630612 Pottapalayam, Sivagangai District, Tamil Nadu, India
}

This work deals an experimental study on wear behaviour of friction stir welded dissimilar AA6101-T6 and AA1350 aluminium alloys. The weldments are fabricated by varying tool traversing speed $(78-120 \mathrm{~mm} / \mathrm{min})$, rotational speed (765-1070 rpm), and tilt angle $\left(0^{\circ}-2^{\circ}\right)$. Effects of tool traversing speed, rotational speed, and tilt angle on wear behaviour of weld zone are analysed by conducting wear tests, measuring microhardness values and examining microstructural images of worn surfaces. Taguchi technique is used to analyse the effects of each welding parameter on wear behaviour. The results of this work indicate that the tool rotating speed is the most influencing parameter on the wear rate of weldments, when compared to traversing speed and tilt angle.

Key words: friction stir welding, weight loss, microhardness, Taguchi technique.

Роботу присвячено експериментальному дослідженню зносостійкості зварних з'єднань різнорідних алюмінієвих стопів АА6101-Т6 та АA1350. Зварні шви було виготовлено при різних швидкостях переміщення інструменту (78-120 мм/хв), швидкостях обертання (765-1070 хв ${ }^{-1}$ ) та кутах нахилу $\left(0^{\circ}-2^{\circ}\right)$. Вплив швидкості переміщення інструменту, швидкості обертання та кута нахилу на зносостійкість зони зварювання вивчався шляхом проведення випробувань на зношування, вимірювання значень мікротвердості та вивчення мікроструктурних зображень зношених поверхонь. Для аналізу впливу кожного параметра зварювання на зносостійкість використовувалася техніка Тагучі. Результати цієї роботи доводять, що швидкість обертання інструменту є параметром, котрий найбі-

Corresponding author: R. Ashok Kumar

E-mail: ashok.hail@gmail.com

Citation: R. Ashok Kumar and M. R. Thansekhar, Wear Behaviour of Friction Stir Welded Dissimilar Aluminium Alloys, Metallofiz. Noveishie Tekhnol., 41, No. 2: 203-211 (2019), DOI: 10.15407/mfint.41.02.0203. 
льше впливає на швидкість зносу зварних конструкцій в порівнянні зі швидкістю переміщення та кутом нахилу.

Ключові слова: зварювання тертям з ворушінням, втрата ваги, мікротвердість, техніка Тагучі.

Работа посвящена экспериментальному исследованию износостойкости сварных соединений разнородных алюминиевых сплавов АА6101-Т6 и AA1350. Сварные швы были изготовлены при различных скоростях перемещения инструмента (78-120 мм/мин), скоростях вращения (7651070 мин $\left.^{-1}\right)$ и углах наклона $\left(0^{\circ}-2^{\circ}\right)$. Влияния скорости перемещения инструмента, скорости вращения и угла наклона на износостойкость зоны сварки изучались путём проведения испытаний на износ, измерения значений микротвёрдости и изучения микроструктурных изображений изношенных поверхностей. Для анализа влияния каждого параметра сварки на износостойкость использовалась техника Тагучи. Результаты этой работы доказывают, что скорость вращения инструмента является параметром, наиболее влияющим на скорость износа сварных конструкций по сравнению со скоростью перемещения и углом наклона.

Ключевые слова: сварка трением с шевелением, потеря веса, микротвёрдость, техника Тагучи.

(Received July 11, 2018)

\section{INTRODUCTION}

Aluminium is approximately three times lighter than steel with a density of $2.7 \mathrm{~g} / \mathrm{cm}^{3}$. As aluminium alloys are lightweight construction materials, they are widely considered in many applications. Hence, many industries have paid their attention towards fabricating lightweight structures [1]. Aluminium alloys are very difficult to join using fusion welding techniques because of formation of porosity and hot cracking [2]. Friction stir welding (FSW) is a non-traditional welding method adopted for joining materials, which are difficult to weld by traditional methods [3-5]. In FSW, important parameters in deciding the quality of joint are traversing speed, rotating speed, tool geometry, axial load, and tool tilt angle [6, 20]. Ashok Kumar et al. [7] found that tool with hexagonal pin has highest joint efficiency, when compared to triangular and square pins. They also investigated the tensile and bending properties of friction stir welded AA6101-T6 and AA1350 aluminium alloys [8].

Wear is a major issue of any component, because it affects the overall efficiency of assembly [9]. Wear test can be conducted in two ways, by varying load with constant sliding speed or by varying sliding speed with constant load [10, 11]. Palanivel et al. [12] found that straight pin profiled tools yield high wear resistance while friction stir welding of AA6351 and AA5083 alloys. Ashok Kumar et al. [13] reported that 
wear resistance is directly proportional to hardness, while reinforcing alumina particles at the interface region of AA6101-T6 and AA1350 alloys. Kumar et al. [14] analysed the wear characteristics of 6061-T6 aluminium alloys by weight differences of before and after wear. Mustafa Gunay et al. [15] used Taguchi method for determining the effects of cutting parameters on surface roughness and optimal cutting parameter combinations during turning of white cast iron. Chi-Hui Chien et al. [16] identified that pin length of tool is the most significant welding parameter for joining AA5083 alloys using ANOVA. From the literature review, no investigation has been done on wear behaviour of friction stir welded dissimilar AA6101-T6 and AA1350 aluminium alloys for different levels of tool traversing speed, rotational speed and tilt angle. In order to minimize the wear rate, Taguchi method has been used to optimize the weld parameters. The weld joints of AA6101-T6 and AA1350 alloys were fabricated with varying traversing speed $(78-120 \mathrm{~mm} / \mathrm{min})$, rotational speed $(765-1070 \mathrm{rpm})$ and tilt angle $\left(0^{\circ}-2^{\circ}\right)[8]$.

\section{EXPERIMENTAL PROCEDURE}

AA6101-T6 and AA1350 aluminium plates with $150 \times 50 \times 6 \mathrm{~mm}^{3}$ are used as base metals to make butt weld joints. In this process, AA6101T6 plate is placed in advancing side whereas AA1350 plate is placed in retreating side. Chemical compositions and properties of AA6101-T6 and AA1350 alloys are given in Ref. [8] and are represented in Tables 1 and 2 . Butt weld joints were fabricated by varying traversing speed $(78-120 \mathrm{~mm} / \mathrm{min})$, rotational speed $(765-1070 \mathrm{rpm})$, and tilt angle $\left(0^{\circ}-2^{\circ}\right)$. Levels of welding parameters are taken from Ref. [8] and are shown in Table 3.

HSS tool with hexagonal pin of $5 \mathrm{~mm}$ pin diameter and $15 \mathrm{~mm}$ shoulder diameter was used for making butt joints. To analyse the wear behaviour of each joint, wear test, hardness test and microstructural analysis were carried out. For wear tests, $16 \mathrm{~mm}$ diameter circular pieces were cut at weld nugget. The wear tests were carried out using rotary drum abrasion resistance tester. Microhardness values across the weld zone were measured using Wilson Wolpert micro Vickers Hardness Tester. Microstructures of worn surfaces were examined using METSCOPE-1A metallurgical microscope.

\section{TAGUCHI TECHNIQUE}

In Taguchi technique, to evaluate the performance level of process parameters, objective functions are converted into signal to noise $(S / N)$ ratio. Generally, three types of objective functions are there. They are smaller-the-best, nominal-the-best and larger-the-best. Weight loss is 
TABLE 1. Chemical compositions (\% wt.).

\begin{tabular}{ccc}
\hline Elements & AA6101T-6 & AA1350 \\
\hline $\mathrm{Al}$ & 97.50 & 99.50 \\
$\mathrm{Si}$ & 0.60 & 0.08 \\
$\mathrm{Fe}$ & 0.35 & 0.36 \\
$\mathrm{Cu}$ & 0.10 & 0.02 \\
$\mathrm{Mn}$ & 0.10 & 0.01 \\
$\mathrm{Mg}$ & 0.90 & $\mathrm{Nil}$ \\
$\mathrm{Zn}$ & 0.10 & 0.01 \\
$\mathrm{Ti}$ & 0.10 & 0.01 \\
$\mathrm{Cr}$ & 0.10 & $\mathrm{Nil}$ \\
$\mathrm{V}$ & $\mathrm{Nil}$ & 0.01 \\
Others & 0.15 & $\mathrm{Nil}$ \\
Elements & AA6101T-6 & AA1350 \\
\hline
\end{tabular}

TABLE 2. Properties.

\begin{tabular}{ccc}
\hline Base Metals & AA6101T-6 & AA1350 \\
\hline Hardness, VHN) & 69 & 39 \\
Weight loss, $\%$ & 6.34 & 10.78 \\
\hline
\end{tabular}

TABLE 3. Levels of welding parameters.

\begin{tabular}{c|c|c|c}
\hline Welding parameters & Level 1 & Level 2 & Level 3 \\
\hline A-Rotating speed, rpm & 765 & 910 & 1070 \\
B-Traversing speed, mm/min & 78 & 100 & 120 \\
C-Tilt angle, ${ }^{\circ}$ & 0 & 1 & 2 \\
\hline
\end{tabular}

directly proportional to wear rate, i.e., when the weight loss is high, wear rate is also high. Hence, wear rate is calculated in terms of weight loss. Here, the objective function is to minimise the wear rate. Hence, smaller-the-best $S / N$ ratio has been calculated. $S / N$ ratio for smallerthe-best is calculated as follows:

$$
S / N=-10 \lg \left(n^{-1} \sum_{i=1}^{n} y_{i}^{-2}\right)
$$

All the calculated $S / N$ ratio values are listed in Table 4.

From the Table, best combination values for minimizing weight loss are rotational speed of $1070 \mathrm{rpm}$, traversing speed of $78 \mathrm{~mm} / \mathrm{min}$ and tilt angle of $2^{\circ}$. Response table is used to identify the most significant process parameter. 
TABLE 4. Taguchi $\mathrm{L}_{9}\left(3^{3}\right)$ orthogonal array.

\begin{tabular}{|c|c|c|c|c|c|}
\hline \multirow{2}{*}{ Experiment } & \multirow{2}{*}{\begin{tabular}{|} 
Rotating \\
speed, rpm
\end{tabular}} & \multirow{2}{*}{$\begin{array}{c}\text { Traversing } \\
\text { speed, } \mathrm{mm} / \mathrm{min}\end{array}$} & \multirow{2}{*}{ Tilt angle, } & \multicolumn{2}{|c|}{ Weight loss at weld zone } \\
\hline & & & & Result, \% & $S / N$ ratios, $\mathrm{dB}$ \\
\hline 1 & 765 & 78 & 0 & 10.26 & -20.2229 \\
\hline 2 & 765 & 100 & 1 & 8.84 & -18.9290 \\
\hline 3 & 765 & 120 & 2 & 9.76 & -19.7890 \\
\hline 4 & 910 & 78 & 1 & 8.78 & -18.8699 \\
\hline 5 & 910 & 100 & 2 & 8.60 & -18.6900 \\
\hline 6 & 910 & 120 & 0 & 8.58 & -18.6697 \\
\hline 7 & 1070 & 78 & 2 & 7.69 & -17.7185 \\
\hline 8 & 1070 & 100 & 0 & 8.59 & -18.6799 \\
\hline 9 & 1070 & 120 & 1 & 8.82 & -18.9094 \\
\hline
\end{tabular}

TABLE 5. Response table for signal to noise ratios for weight loss.

\begin{tabular}{c|c|c|c}
\hline Level & Rotating speed, rpm & Traversing speed, mm/min & Tilt angle, $^{\circ}$ \\
\hline 1 & -19.65 & -18.94 & -19.19 \\
2 & -18.74 & -18.77 & -18.90 \\
3 & -18.44 & -19.12 & -18.73 \\
Delta & 1.21 & 0.36 & 0.46 \\
Rank & 1 & 3 & 2 \\
\hline
\end{tabular}

TABLE 6. ANOVA for weight loss. Here: DF is degree of freedom, SS is sum of squares, MS is mean of squares, PCR is percentage of contribution.

\begin{tabular}{c|c|c|c|c|c|c}
\hline Factors & DF & SS & MS & $F$ ratio & $P$ value & PCR, $\%$ \\
\hline A & 2 & 2.587 & 1.2937 & 4.37 & 0.067 & 59.31 \\
B & 2 & 0.2169 & 0.1084 & 0.16 & 0.858 & 4.97 \\
C & 2 & 0.3374 & 0.1687 & 0.25 & 0.785 & 7.73 \\
Error & 2 & 1.2213 & 0.6107 & & & 27.99 \\
Total & 8 & 4.3626 & & & & \\
\hline
\end{tabular}

From Table 5, one can conclude that rotating speed is the most influencing parameter on weight loss whereas traversing speed is the least influencing parameter on weight loss.

ANOVA table is used to identify the percentage contribution of each parameter. Table 6 represents the statistical contribution details of tool traversing speed, rotational speed and tilt angle on weight loss. Highest percentage contribution $(59.31 \%)$ on weight loss is made by tool rotating speed. 


\section{RESULTS AND DISCUSSIONS}

\subsection{Effects of Welding Parameters}

\subsubsection{Tool Rotational Speed}

Frictional heat generation during welding is directly proportional to tool rotational speed [8]. Hence, higher rotational speed results in higher heat generation. This plasticizes the metals more, which improves the flow characteristics of material in stir zone. Thus, better mixture of metal occurs. On the other hand, lower rotational speed produces insufficient heat, which reduces the plasticization and flow behaviour of materials.

\subsubsection{Tool Traversing Speed}

Cooling rate during welding is directly proportional to tool traversing speed [8]. Lower traversing speed lowers the cooling rate whereas higher traversing speed enhances the rate of cooling. During higher rate of cooling, material quickly returns to its solid state from plasticized state which results insufficient flow of material during stirring. On the other hand, lower cooling rate delays the transformation of material from plasticized state to its solid state, which causes sufficient flow of material.

\subsubsection{Tool Tilt Angle}

Tool tilt against travelling direction gives additional downward force and heat input to leading side [8]. To attain a good bonding at stir zone, applied force should be higher than flow stress of the materials. Higher tool tilt angle results in higher applied force. Thus, higher bonding occurs at higher tool tilt.

\subsection{Microstructural Analyses}

Lee et al. [17] found that $\mathrm{Mg}_{2} \mathrm{Si}$ precipitates are formed and homogeneously distributed while welding of A356 and AA6061 aluminium alloys. Donatus et al. [18] determined that recovery of $\mathrm{Mg}_{2} \mathrm{Si}$ precipitates is based on heat generation during joining AA5083 and AA6082 alloys. They also observed that reprecipitation of $\mathrm{Mg}_{2} \mathrm{Si}$ precipitates influence the hardness distribution of joints. Thus, whenever 6000 series alloys are involved, $\mathrm{Mg}_{2} \mathrm{Si}$ precipitates are formed. Temperature at stir zone is based on heat generation during welding. These precipitates get grow and dissolved at insufficient heat input and reprecipitated at suf- 


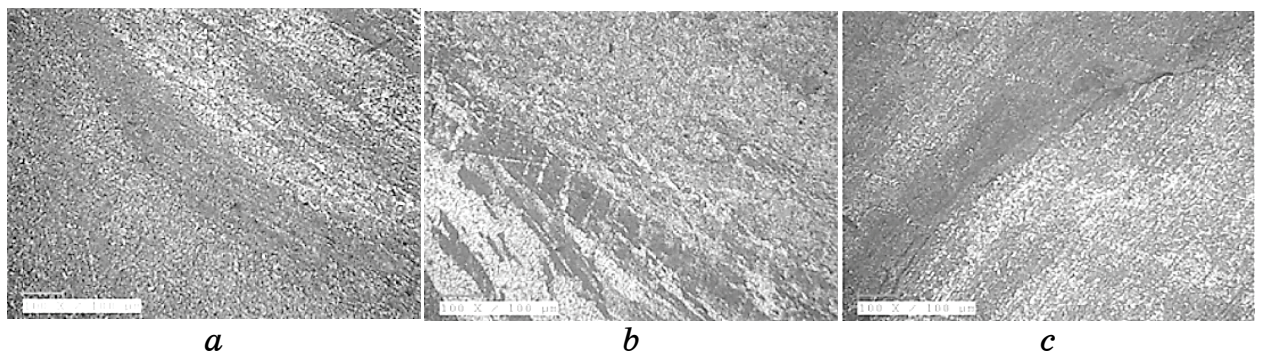

Fig. 1. Optical micrograph at weld zone for experiments No. $7(a)$, No. $1(b)$ and No. $3(c)$.

ficient heat input [19]. Experiment No. 7 provides high heat generation and low cooling rate, which produces high heat input during welding. At this temperature, precipitates get dissolved and some of them get reprecipitated in aluminium matrix (Fig. 1,a). This reprecipitation process results in high hardness (Fig. 2) at stirred zone. Whenever hardness increases, wear resistance also increases [13]. Hence, minimum weight loss is observed.

However, experiment No. 1 was carried out at $765 \mathrm{rpm}$ rotating speed, $78 \mathrm{~mm} / \mathrm{min}$ traversing speed and $0^{\circ}$ tilt angle. Thus, low heat generation produces low temperature at stir zone. This temperature is just enough to grow the precipitates (Fig. 1, $b$ ), which lowers the hardness at nugget zone (Fig. 2) and consequently, weight loss is high. Depending upon the heat input variation, percentage of precipitate growth, dissolution and reprecipitation are varied. Thus, temperature increases gradually up to experiment No. 7, which causes gradual increment in hardness (Fig. 3). However, in experiment No. 3, cooling rate is high that lowers the temperature at stirred zone. Hence, more discontinuities are observed at stirred zone (Fig. 1, c). As a result of this, hardness is low, when compared to experiment No. 2. After experiment No. 7 , heat generation gradually decreases that reduces the temperature as well as hardness at weld nugget that increases the wear rate.

\section{CONCLUSIONS}

In this investigation, wear behaviour of friction stir welded AA6101T6 and AA1350 aluminium alloys are studied. The welding parameters with respect to wear characteristics are optimized using Taguchi $\mathrm{L}_{9}$ orthogonal array.

The welded joints fabricated with $1070 \mathrm{rpm}$ rotating speed, 78 $\mathrm{mm} / \mathrm{min}$ traversing speed and $2^{\circ}$ tilt angle exhibits higher wear resistance. The tool rotating speed contributes extensively with the per- 


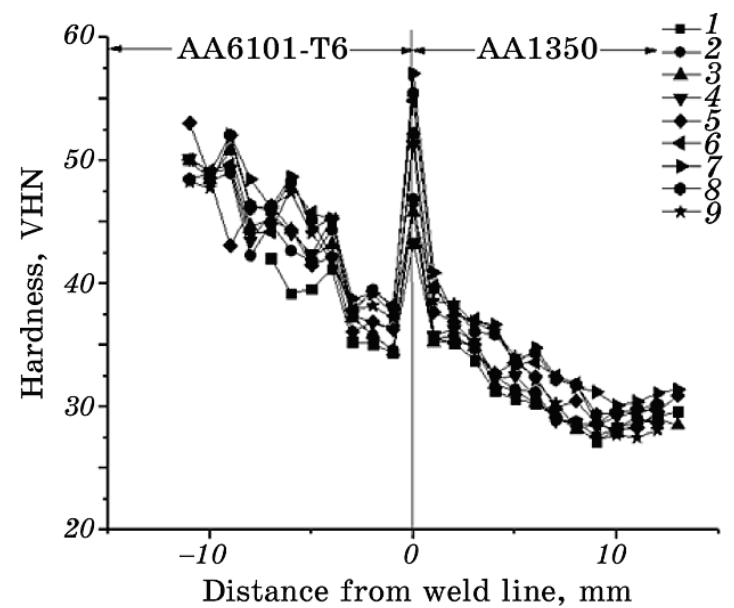

Fig. 2. Hardness plot.

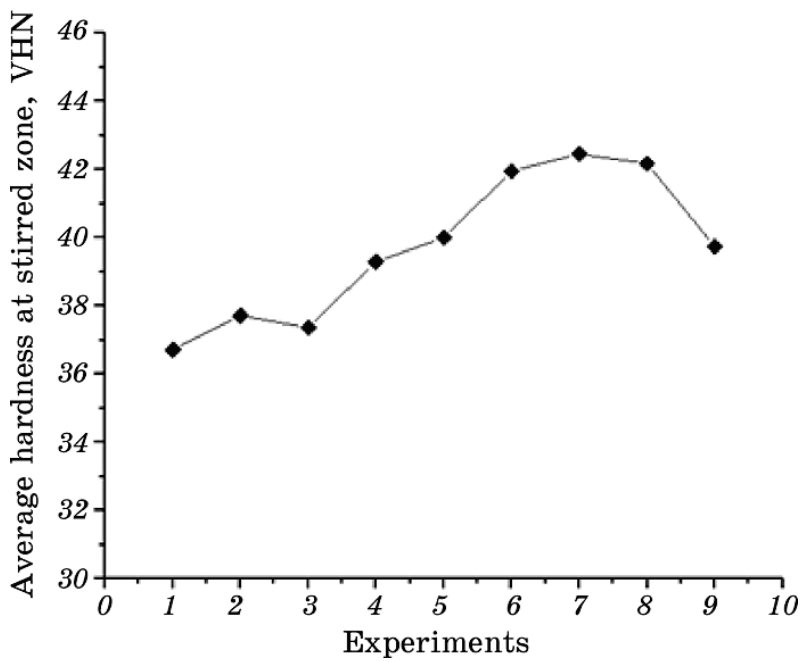

Fig. 3. Average hardness at stirred zone.

centage of 59.31 on wear characteristics. Reprecipitation process increases hardness as well as wear resistance. At the same time, dissolution and growth of precipitates reduce hardness as well as wear resistance.

\section{REFERENCES}

1. P. Carlone, R. Citarella, M. R. Sonne, and J. H. Hattel, Int. J. of Fatigue, 90: 69 
(2016).

2. L. Quintino, R. Miranda, U. Dilthey, D. Iordachescu, M. Banasik, and S. Stano, Adv. Struct. Mater., 8: 33 (2012).

3. C. G. Rhodes, M. W. Mahoney, W. H. Bingel, R. A. Spurling, and

C. C. Bampton, Scripta Mater., 36, Iss. 1: 69 (1997).

4. H. B. Chen, K. Yan, T. Lin, S. B. Chen, C. Y. Jiang, and Y. Zhao, Mater. Sci. Eng. A, 433: 64 (2006).

5. R. Ashok Kumar and M. R. Thansekhar, J. Mech. Sci. Tech., 32, Iss. 7: 3299 (2018).

6. P. Cavaliere, Procedia CIRP, 11: 139 (2013).

7. R. A. Kumar and M. R. Thansekhar, Advanced Materials Research, 984-985: 586 (2014).

8. R. A. Kumar and M. R. Thansekhar, Materials Science, 23, Iss. 1: 78 (2017).

9. S. Das, Trans. of Indian Inst. of Met., 57, Iss. 4: 325 (2004).

10. J. Victoria-Hernandez, D. Hernandez-Silva, and M. Vite-Torres, Wear, 267: 340 (2009).

11. K. Gopinath, Wear, 71: 161 (1981).

12. R. Palanivel, P. Koshy Mathews, N. Murugan, and I. Dinaharan, Proc. Eng., 38: 578 (2012).

13. R. Ashok Kumar and M. R. Thansekhar, Mater. Res. Express., 5, Iss. 4: 046521 (2018).

14. R. Kumar, S. Chattopadhyaya, S. Hloch, G. Krolczyk, and S. Legutko, Maintenance and Reliability, 18, Iss. 1: 128 (2016).

15. M. Gunay and E. Yucel, Measurement, 46: 913 (2013).

16. Ch.-H. Chien, W.-B. Lin, and Th. Chen, J. of the Chinese Inst. of Eng., 34, Iss. 1: 99 (2011).

17. W. B. Lee, Y. M. Yeon, and S. B. Jung, Scripta Metall., 49: 423 (2003).

18. U. Donatus, G. E. Thompson, X. Zhou, J. Wang, and K. Beamish, Mater. Design, 83: 203 (2015).

19. K. Kumar and S. V. Kailas, Mater. Design, 29: 791 (2008).

20. R. Ashok Kumar and M. R. Thansekhar, Int. J. Applied Eng. Research, 10, Iss. 8: 6337 (2015). 